\title{
Introduction
}

\section{Spaces, places and the power of ideas}

\author{
Karin van Marle
}

Department of Public Law, University of the Free State, 205 Nelson Mandela Dr, Park West, Bloemfontein

9301; E-mail: VanMarlek@ufs.ac.za

I felt as though I were looking down to the bottom of myself, and what I found there was more than just myself - I found the world.

-Paul Auster, The inverntion of solitude

L vents that have taken place at several South African universities since 2015 have disclosed many fault lines in the social, political and legal arena. One aspect among many others is the extent to which the idea of the university as a public space has been attacked and all spaces of 'action and speech' are under siege. The university as a microcosm of society in general reflects a similar decline of public space, erasure of possibilities for radical dissent and the impossibility of even getting closer to a sense of justice experienced in other spaces. However as the contributions in this edition show it is not only universities and not only South African society that are burdened by neoliberal power.

In this special edition authors tackle these issues from various angles: how the theoretical conjuncture of 'state of exception' materialised not only on university campuses but also in other spaces; how ever-expanding disciplinary jurisdiction abolished all possibilities for protest and dissent; on a more hopeful note, what role could architecture, utopia and the politics of inhabitance play; how could aesthetics, poetry, narratives push back against the endurance of past, and expansion of present, injustice?

Two contributions address issues in Australia: Chris Butler explores the problem of public housing in Australia and laments the brutalist design present in many public housing projects. On a more optimistic note he contemplates the possibility of "inhabitance" that could include "bodily occupation"; "creative appropriation 
of space" and "the possibility of utopia". Sarah Keenan and Nadine El-Enany focus on protests that took place at Australia House in London against its policy on migrants arriving on boats. They relate the present position to Australia's "racist colonial founding".

Moving to the South African context four articles respond directly to the student protests of 2015-2016. Isolde de Villiers is interested in thinking about the relation between the university as public space and the city. She draws connections between marches to the Union Buildings and marches to the administration building on the UP campus, notoriously known as "Die skip" (the Ship). Emmanuel Kamdem Kamga and Michael Bongani Reinders both focus on the violence and militarisation of university campuses. Reinders tentatively considers if this force and increasing militarisation could be seen as manifestations of fascism. Kamdem Kamga, drawing on the notion of the state of exception, shows how the 'camp' has moved away from its initial location and considers the extent to which the campus resembles the camp. Karin van Marle reflects on the extent to which 'rights' have played a progressive/radical role in the student protests and drawing on spatial theory considers the notion of a "right to the university". For her this right to the university could have "inhabitance" at its core and might be able to invoke, or might at least encourage us to (re)imagine the university beyond the tables, grids and spreadsheets that have become the dominant intellectual sensibility.

Keneilwe Radebe invokes the spirit of the late Nat Nakasa to reflect on the challenge of the SABC 8 to the SABC protest policy restricting media reportage on public protests. Relating to the theme of continuity present also in the contributions of Keenan and El-Nanny and Barnard-Naude, she is concerned with the extent to which media freedom in present day South Africa is curbed. She argues that similar to the Nat Nakasa era a culture of fear and silence is slowly being instilled in journalists by the state-owned SABC. Isaac Shai, in a reflection on the possibility of radical transformation, argues that the law and in particular the notion of transformative constitutionalism is too limited to carry radical transformation. He argues that while the dominant narrative on the inability to radically transform South Africa is predominantly attributed to corruption, racism and state incapacity, among others law, constitutionalism and human rights should also be scrutinised. The final article, by Jaco Barnard-Naude, draws on and engages with a piece authored in 1988 by legal theorist Lourens du Plessis on 'Calvinism'. Barnard-Naude is concerned about the return to fraternity in global and local politics. He calls for an appeal for "universal love" and the hope of a political relation that can assists us to live differently, less violently and more justly. 
Disheartened by the ever-exceeding power of neoliberalism with its emphasis on individual gain, and commodification of everything that inevitably leads to the death of thought, authors explore possibilities for the life of the mind, relationality and, even if 'inoperative', community. 